\title{
Resistant Hypertension: A Clinical Case
}

\section{Hipertensión resistente: un caso clínico}

\section{Hipertensão resistente: um caso clínico}

\author{
Joana Cascais Costa, $\mathrm{MD}^{1 *}$; \\ João Rua, $\mathrm{MD}^{1}$; \\ Amílcar Silva, MD'; \\ Adriano Rodrigues, MD PhD ${ }^{1}$
}

Received: January 23, 2018 / Accepted: May 22, 2018

Dor: http://dx.doi.org/10.12804/revistas.urosario.edu.co/revsalud/a.7272

To cite this article: Cascais-Costa J, Rua J, Silva A, Rodrigues A. Resistant Hypertension: A Clinical Case. Rev Cienc Salud.

2018;16(3):571-77. DoI: http://dx.doi.org/10.12804/revistas.urosario.edu.co/revsalud/a.7272

\section{Abstract}

Introduction: Secondary hypertension corresponds to $15 \%$ of the causes of arterial hypertension, and among them, primary hyperaldosteronism presents a variable incidence of about $3 \%$ in hypertensive patients. It has a slightly higher prevalence in women, between 30 and 60 years, and is usually unilateral. Case presentation: The authors describe the clinical case of a patient, followed by a severe hypertension medicated with four antihypertensive drugs for tension stabilization, maintaining systolic arterial tensions superior to $170 \mathrm{mmHg}$. In the aetiological study of hypertension, analytical alterations suggested hyperaldosteronism and a nodular lesion was detected in the left adrenal gland. The patient was submitted to surgery and excision of the lesion was done with histological confirmation of the diagnosis of corticomedullary adenoma of the adrenal gland. The patient presented improvement of the tension profile, with need to suspend two of the four antihypertensive drugs and to reduce the dose of the remaining ones. Conclusion: A tumor of the adrenal cortex producing aldosterone is the main cause of primary hyperaldosteronism and should always be excluded when the presence of difficult to control, severe hypertension is detected, since the standard treatment is surgical, leading to a stabilization of the tension pattern after a few months.

Keywords: Conn's adenoma, adrenal adenoma, arterial hypertension, secondary hypertension, primary aldosteronism, resistant hypertension.

\section{Resumen}

Introducción: la hipertensión secundaria corresponde al 15\% de las causas de hipertensión arterial, y entre ellas, el hiperaldosteronismo primario presenta una incidencia variable de sobre $3 \%$ en pacientes hipertensos. Tiene una prevalencia ligeramente mayor en mujeres, entre 30 y 60 años, y generalmente es unilateral. Presentación del caso: los autores describen el caso clínico de un paciente, seguido por una hipertensión resistente medicada con cuatro fármacos antihipertensivos para la estabilización de

1 Serviço de Medicina Interna B, Hospital Geral do Centro Hospitalar e Universitário de Coimbra, Coimbra, Portugal.

Corresponding autor: joanacascaiscosta@gmail.com 
la tensión, con mantenimiento de las tensiones arteriales sistólicas superiores a $170 \mathrm{mmHg}$. Las alteraciones analíticas en el estudio etiológico de la hipertensión sugirieron hiperaldosteronismo y una lesión nodular en la glándula suprarrenal izquierda. El paciente fue sometido a cirugía y se realizó la escisión de la lesión con confirmación histológica del diagnóstico de adenoma corticomedular de la glándula suprarrenal. El paciente presentó una mejora en el perfil de tensión, con la necesidad de suspender dos de los cuatro fármacos antihipertensivos y reducir la dosis de los restantes. Discusión: un tumor de la corteza suprarrenal que produce la aldosterona es la principal causa de hiperaldosteronismo primario y siempre debe excluirse cuando se presenta hipertensión grave, difícil de controlar, ya que el tratamiento estándar es quirúrgico y conduce a una estabilización del patrón de tensión después de unos meses.

Palabras clave: adenoma de Conn, adenoma adrenal, hipertensión arterial, hipertensión secundaria, aldosteronismo primario, hipertensión resistente.

\section{Resumo}

Introdução: a hipertensão secundária corresponde ao $15 \%$ das causas de hipertensão arterial, e entre elas, o hiperaldosteronismo primário apresenta uma incidência variável de sobre $3 \%$ em pacientes hipertensos. Tem uma prevalência ligeiramente maior em mulheres, entre 30-60 anos, e geralmente é unilateral. Apresentação do caso: os autores descrevem o caso clínico de um paciente, seguido por uma hipertensão resistente medicada com quatro fármacos anti-hipertensivos para a estabilização da tensão, com manutenção das tensões arteriais sistólicas a $170 \mathrm{mmHg}$. As alterações analíticas no estudo etiológico da hipertensão sugeriram hiperaldosteronismo e uma lesão nodular na glândula suprarrenal esquerda. O paciente foi submetido a cirurgia e se realizou a incisão da lesão com confirmação histológica do diagnóstico de adenoma córtico-medular da glândula suprarrenal. O paciente apresentou uma melhora no perfil de tensão, com a necessidade de suspender dois dos quatro fármacos anti-hipertensivos e reduzir a dose dos restantes. Discussão: um tumor do córtex suprarrenal que produz a aldosterona é a principal causa de hiperaldosteronismo primário e sempre deve excluir-se quando se apresenta hipertensão grave, difícil de controlar, pois o tratamento standard é cirúrgico e conduz a uma estabilização do patrão de tensão depois de uns meses.

Palavras-chave: Conn’s adenoma, adrenal adenoma, hipertensão arterial, hipertensão secundária, aldosteronismo primário, hipertensão resistente.

\section{Introduction}

Cecondary hypertension corresponds to $15 \%$ of the causes of arterial hypertension, and among them, primary hyperaldosteronism is the most common cause of reversible hypertension, with a very characteristic clinical frame. It has a slightly higher prevalence in women, between 30 and 60 years, and is usually unilateral.

An aldosterone producing tumor of the adrenal cortex is the main cause of primary hyperaldosteronism and should always be excluded when in the presence of severe hypertension, since the standard treatment is surgical and leads to a stabilization of the tension pattern after a few months. 


\section{Case presentation}

The authors describe the clinical case of a 63-year-old male patient who presented with a severe hypertension with five years of evolution, treated with four antihypertensive agents (nifedipine 60mg daily, losartan 100mg daily, nebivolol $5 \mathrm{mg}$ daily, and rilmenidine $1 \mathrm{mg}$ daily) introduced sequentially, maintaining systolic blood pressure [вр] greater than $170 \mathrm{mmHg}$, with progressive worsening in the last two years. He is an autonomous patient, with history of non-insulin treated type 2 diabetes mellitus and a stroke, four years previously, without chronic sequelae. In the etiological study of hypertension, several analytical alterations were identified, and they are explained in table 1.

Table 1. Representation of the analytical alterations

\begin{tabular}{cccc}
\hline & Patient values & & Reference values \\
\hline Potassium & $3.19 \mathrm{mmol} / \mathrm{L}$ & $\downarrow$ & $3.5-5-1 \mathrm{mmol} / \mathrm{L}$ \\
\hline Aldosterone & $21.9 \mathrm{ng} / \mathrm{mL}$ & $\uparrow$ & $>20 \mathrm{ng} / \mathrm{mL}$ \\
\hline Active renin & $0.8 \mathrm{uU} / \mathrm{mL}$ & $\downarrow$ & $7-76 \mathrm{uU} / \mathrm{mL}$ \\
\hline Aldosterone / active renin index & $27.4 \mathrm{ng} / \mathrm{mL} / \mathrm{h}$ & $\uparrow$ & $>25 \mathrm{ng} / \mathrm{mL} / \mathrm{h}$ \\
\hline $\begin{array}{c}\text { Vanilmandelic acid } \\
\text { (Urinary) }\end{array}$ & $7.46 \mathrm{mg} / 24 \mathrm{~h}$ & $\uparrow$ & $2.0-7.0 \mathrm{mg} / 24 \mathrm{~h}$ \\
\hline $\begin{array}{c}\text { Metanephrines and } \\
\text { normetanephrines } \\
\text { (Urinary) }\end{array}$ & $114 \mathrm{mcg} / 24 \mathrm{~h}$ & $\downarrow$ & $<350 \mathrm{mcg} / 24 \mathrm{~h}$ \\
\hline
\end{tabular}

By ultrasonography, a nodular lesion was detected on the left adrenal gland (figure 1) which was subsequently confirmed by abdominal ст, showing a solid lesion of about $2.5 \mathrm{~cm}$ on the left adrenal gland. The patient was submitted to surgery and the lesion was excised with histological confirmation of a corticomedullary adenoma of the adrenal gland.

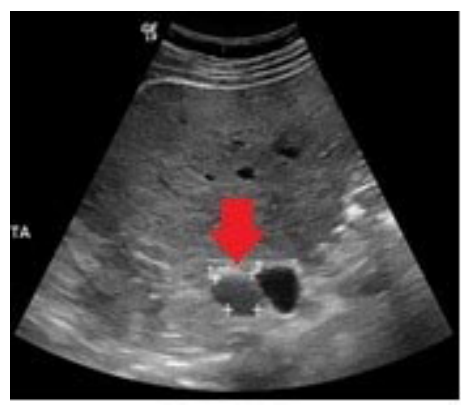

Figure 1. Echographic image of Conn's adenoma 
The patient presented improvement in his ambulatory blood pressure profile (with systolic вР around $130 \mathrm{mmHg}$ ), and confirmed in $24 \mathrm{~h}$ ambulatory blood pressure monitoring (systolic вр 113-138 mm Hg and diastolic BP 66-78 mm Hg) seven months after the procedure, despite suspending two of the four antihypertensive drugs (nebivolol and rilmenidine, the latter still during the admission) and reducing the dose of the remaining ones (nifedipine to $30 \mathrm{mg}$ daily, losartan to $50 \mathrm{mg}$ daily). For the time being the patient maintains normalized aldosterone/active renin index and no hypokalemia.

\section{Discussion}

Yypertension causes significant morbidity and mortality worldwide, having a prevalence $(1,2)$. Hypertension has the largest prevalence of all cardiovascular risk factors and, due to its deleterious effects on the cardiovascular and renal systems, it is considered responsible for $45 \%$ of the heart disease related deaths and $51 \%$ of them due to stroke $(1,3)$.

The prevalence of hypertension increases with age and most individuals with hypertension are diagnosed with primary hypertension. Primary hypertension accounts for approximately $85 \%$ of the diagnosed cases. It is estimated that approximately $15 \%$ of hypertensive patients have identifiable conditions that result in blood pressure elevation (secondary hypertension) (4).

Common causes of secondary hypertension include obstructive sleep apnea, renal artery stenosis, chronic kidney disease, and endocrine alterations (3, 4, 5). Endocrine hypertension accounts for approximately $3 \%$ of the secondary forms of hypertension and is a term assigned to states in which hormonal derangements result in clinically significant hypertension (4). The most common causes of endocrine hypertension are excess production of mineralocorticoids (primary hyperaldosteronism), catecholamines (pheochromocytoma), thyroid hormone, and glucocorticoids (Cushing syndrome) (4).

Primary hyperaldosteronism is the most common cause of reversible hypertension, with a reported prevalence of $5 \%$ to $20 \%$, and presents in a myriad of clinical scenarios (1, $4,6)$. Adrenocortical adenoma is the most common adrenal tumor. Because the majority of adenomas are non-functioning, most of these lesions are detected incidentally on routine imaging performed for unrelated reasons (7).

Primary aldosteronism is characterized by autonomous production of aldosterone by the adrenal glands along with suppressed renin production by the renal juxtaglomerular apparatus. This leads to volume expansion, severe hypertension, metabolic alkalosis, and hypokalemia $(1,5,6,8)$. Classically, excessive aldosterone secretion in primary hyperaldosteronism not only results in difficult to manage hypertension in the majority of 
patients, but also produces biochemical effects of hypokalemia in $10 \%$ to $30 \%$ of patients (1). In many occasions, primary hyperaldosteronism is completely asymptomatic. When symptoms occur, they are usually secondary to hypertension or the resulting hypokalemia: cramps and fatigue; cardiac arrhythmias, manifested by palpitations; progressive weakness, even reporting cases of generalized paralysis; polydipsia and polyuria due to diabetes insipidus induced by hypokalemia (8). It is important to identify the existence of primary aldosteronism among resistant hypertensive patients since it is frequently curable, with clear reduction in disease burden (9).

Mineralocorticoid receptor antagonists absolutely interfere with the interpretation of the aldosterone/renin plasmatic index and should be discontinued at least six weeks before testing $(8,10)$. Angiotensin converting enzyme inhibitors and angiotensin receptor blockers falsely increase plasma renin activity; therefore, a useful clinical point is that when plasma renin activity is undetectably low in a patient taking this type of medication, primary aldosteronism is suspected (10). Although it is the most used screening method in patients with suspected primary hyperaldosteronemia, given the low prevalence of this condition, the screening tests are reserved for those patients with resistant hypertension or hypertension associated with hypokalemia (even when hypokalemia is suspected to be secondary to the use of diuretics) (8).

The elevation of the aldosterone/renin index is a sensitive but not specific test, so that confirmatory tests are necessary in patients with elevated indexes (10).

There are four suppression tests used to confirm the alterations: oral sodium load, oral fludrocortisone load, oral captopril load and saline infusion to suppress aldosterone secretion; with the first and last being the most commonly used (10).

There is also an adrenal venous sampling, which is considered the gold-standard test to distinguish between unilateral or bilateral disease in patients with primary aldosteronism who desire surgical treatment of their hypertension. It is done by catheterization of femoral venous access, sampling blood from both adrenal veins and from the inferior vena cava below the renal veins and measurement of aldosterone and cortisol levels. The aldosterone/ cortisol index should be elevated in secretory tumor (10).

Adrenalectomy is the procedure of choice for unilateral aldosterone-secreting adenomas, while medical therapy is best for bilateral adrenal hyperplasia (1). Biochemical cure following adrenalectomy occurs in $99 \%$ of patients, and hemodynamic improvement is seen in over $90 \%$, prompting a reduction in quantity and dosing of anti-hypertensive medications in most patients (1). End-organ damage secondary to hypertension and excess aldosterone is significantly improved by both surgical and medical treatment $(1,4)$. Resistant hypertension is an increasingly common clinical problem that is often heterogeneous in etiology, risk factors and comorbidities. In light of diagnostic advances, evidence points to higher prevalence of secondary causes of hypertension, about 10 to 
$35 \%$ (5). For diagnosing, patient's history and physical examination are important, as are assessing compliance, regular blood pressure measurement, biochemical evaluation and noninvasive imaging (3).

Although the most common causes of therapeutic failure are undiscovered secondary causes of hypertension and lack of patient compliance, other causes should be suspected, tested and, if confirmed, curable forms of arterial hypertension should be treated (3). Given the large impact on global health, controlling hypertension is of extreme importance (1).

\section{Declaration of Interest}

The authors report no conflicts of interest.

\section{References}

1. Aronova A, III TJF, Zarnegar R. Management of hypertension in primary aldosteronism. World J Cardiol. 2014;6(5):227-33. Dor: 10.4330/wjc.v6.i5.227

2. Catena C, Colussi GL, Brosolo G, Bertin N, Novello M, Palombe A, et al. Salt, aldosterone, and parathyroid hormone: What is the relevance for organ damage? Int J Endocrinol. 2017;2017:4397028. Dor: 10.1155/2017/4397028

3. Prkacin I, Balenovic D, Djermanovic-Dobrota V, Lukac I, Drazic P, Pranjic I-K. Resistant hypertension and chronotherapy. Mater Sociomed. 2015;27(2):118-21. Dor: 10.5455/ msm.2015.27.118-121

4. Koch CA, Chrousos GP. Overview of endocrine hypertension. In: De Groot LJ, Chrousos G, Dungan K, et al., editors. Endotext [internet]. South Dartmouth (MA): MDText.com, Inc.; 2000 [cited 2016 Oct 26]. Available from: https://www.ncbi.nlm.nih.gov/books/ NBK278980/

5. Kumar N, Calhoun DA, Dudenbostel T. Management of patients with resistant hypertension: current treatment options. Integr Blood Press Control. 2013;6:139-151. Dor: 10.2147/ IBPC.S33984

6. Vaidya A, Dluhy R. Hyperaldosteronism. In: De Groot LJ, Chrousos G, Dungan K, et al., editors. Endotext [internet]. South Dartmouth (MA): MDText.com, Inc.; 2000 [cited 2016 Oct 19]. Available from: https://www.ncbi.nlm.nih.gov/books/NBK279065/

7. Park JJ, Park BK, Kim CK. Adrenal imaging for adenoma characterization: imaging features, diagnostic accuracies and differential diagnoses. The British Journal of Radiology. 2016;89(1062):20151018. Dor: 10.1259/bjr.20151018

8. Díaz J, Zúñiga E. Síndrome de Conn: descripción de un caso clínico. Hipertensión (Madr.). 2007;24(4):181-4. 
9. Kim SH, Ahn JH, Hong HC, Choi HY, Kim YJ, Kim NH, et al. Changes in the clinical manifestations of primary aldosteronism. The Korean Journal of Internal Medicine. 2014;29(2):217-225. DoI: 10.3904/kjim.2014.29.2.217

10. Uresti-Flores E, Saucedo-Trevinõ L, Gámez-Barrera H, Melo-Gastón M, Valdés-Cruz E, García-de Léon L. Síndrome de Conn. Med Int Méx 2015;31:210-16. 